\title{
Dental Caries and Associated Determinants among Students of the Military School of Saint Louis (Senegal)
}

\author{
Massamba Diouf ${ }^{*}$, Mababou Kebe2 , Mamadou Lamine Guirassy ${ }^{3}$, Mbathio Diop1, \\ Abdoulaye Diouf4, Aida Kanoute1, Jean-Claude Guinan5, Amadou Dieng1, \\ Abou Dramane Sanghares, Daouda Cisse ${ }^{1}$, Daouda Faye ${ }^{1}$, Cheikh Mbacké Lo ${ }^{1}$ \\ ${ }^{1}$ Public Health Service, Department of Dentistry, Cheikh Anta Diop University, Dakar, Senegal \\ ${ }^{2}$ Dental Office, Military Hospital, Dakar, Senegal \\ ${ }^{3}$ Service of Periodontology, Department of Dentistry, Cheikh Anta Diop University, Dakar, Senegal \\ ${ }^{4}$ Service of Pediatric Dentistry, Department of Dentistry, Cheikh Anta Diop University, Dakar, Senegal \\ ${ }^{5}$ Public Health Service, Faculty of Dentistry, Felix H Boigny University, Abidjan, Côte d'Ivoire \\ Email: ^dioufmass78@yahoo.fr
}

How to cite this paper: Diouf, M., Kebe, M., Guirassy, M.L., Diop, M., Diouf, A., Kanoute, A., Guinan, J.-C., Dieng, A., Sanghare, A.D., Cisse, D., Faye, D. and Lo, C.M. (2017) Dental Caries and Associated Determinants among Students of the Military School of Saint Louis (Senegal). Open Journal of Epidemiology, 7, 299-306.

https://doi.org/10.4236/ojepi.2017.74024

Received: August 7, 2017

Accepted: September 11, 2017

Published: September 14, 2017

Copyright $\odot 2017$ by authors and Scientific Research Publishing Inc. This work is licensed under the Creative Commons Attribution International License (CC BY 4.0).

http://creativecommons.org/licenses/by/4.0/

\begin{abstract}
Introduction: Due to its health, social and economic morbidity, dental caries leads to absenteeism and a drop in school performance among schoolchildren. The objective of this work is to study dental caries and its determinants in pupils known as Children of Troop (CT) of the "Military School of Saint Louis" (MSS). Method: This was a descriptive and cross-sectional study. Recruitment was exhaustive. The collection was made at the school and has covered the period of March 10 throughout June 13, 2014 in an individual interview, based upon a deliberate consent, using a questionnaire drawn up on the basis of the variables studied. The bivariate analysis was done with the Epi Info software version 3.5.3. Results: The mean age of CT was 14.9. The prevalence of caries was $61.2 \%$. Determinants related to caries were: sugar intake between meals $(\mathrm{OR}=6.44[3.4-11.9])$; insufficient tooth brushing $(\mathrm{OR}=14.3[8.8-23.29])$; $(\mathrm{OR}=3.84[2.38-7.14])$ and for regular dental visits $(\mathrm{OR}=5.26[3.44-8.33])$, with the last dental visit dating back more than one year. Conclusion: In the face of challenges of school performance of CT, it is necessary to set up a control plan focusing mainly on the factors identified and associated with dental caries in military school.
\end{abstract}

\section{Keywords}

Military School, Child of Troop, Dental Caries, Determinants 


\section{Introduction}

Dental caries is a microbial, multifactorial disease that succeeds in destroying the hardest substance of the human body, the enamel [1].

This disease is identified by the World Health Organization (WHO) as one of the most important public health issues [2]. Mortality as a consequence of caries is practically non-existent. However, dental caries is an important cause of morbidity. For developing countries such as Senegal, dental caries is a public health concern because of its impact on the quality of life of people suffered from tooth decay and the high cost of care [2]. The consequences and complications of decay are pain, loss of teeth (causing disturbances in occlusion, nutrition, aesthetics and psycho-social life), local, locoregional and focal distance.

The prevalence of caries varies from geographical regions to the availability and accessibility of health services. Social determinants are also very pronounced [3] [4]. During the 20th century, the epidemiological situation of tooth decay has evolved differently in the world. In developed countries, the prevalence has significantly decreased [5] and is attributed to the rise of living standards, generalization of fluoridated toothpastes and means of prevention [6]. The global burden of these diseases is significantly higher among poor and underprivileged population groups [7].

Other determinants such as hygiene level, sugar consumption, individual biological characteristics, intervene in the onset of tooth decay.

Sixty to ninety percent of schoolchildren worldwide have cavities that often cause pain and discomfort. Pulpitis is the main reason for school absenteeism in many countries [8].

Africa is one of the most affected continents by dental caries, especially in school-aged children. In Senegal, tooth decay is also a problem for schoolchildren. In the Dakar region in 2014, a prevalence of $41.8 \%$ was observed among schoolchildren in the age of 12 [9].

The Armed Forces Medical Services contributes to maintaining morale of the troop by taking after of their state of health. In the service, children's health is a special concern. Among these children, some come from military families, but also Children of Troop (C.T) from the "Miltary School of Saint-Louis" (MSS) and a boarding school with military supervision. The objective of this study is to determine the prevalence of dental caries and associated determinants.

\section{Materials and Methods}

This was a descriptive and cross-sectional study. It was based on the MSS, a general secondary school and a military training center in Senegal.

The population under study has consisted of the MSS troop children enrolled during school year 2013/2014. Recruitment was exhaustive; The number of children of troop (C.T) was 485. Students who were unavailable or refused to take part in the survey on the basis of deliberate consent were not included in this study.

Data collection took place at the dental office of Bango military camp where MSS is housed with a WHO survey form adapted to the objectives of this study. 
A pre-test was carried out in a secondary school in Dakar on 50 pupils by the dentist of the dental center of Ouakam military hospital in order to make the necessary final modifications.

An information sheet was administered to each C.T. Participation was free and voluntary. The questionnaire was anonymous and the data collected were confidential and kept in a secure location.

The Epi Info software version 3.5.3 enabled the capture of the data collected. A cleanup of the files was done with the analysis program of the same software for a correction of the outliers' data and errors of input. The results were expressed in mean and proportions in univariate analysis and in odds ratios with their confidence intervals in bivariate. The significance level was 5\%.

\section{Results}

\subsection{Socio-Demographic Characteristics}

At the end of the data collection, 441 people were surveyed from March 10 throughout June 13, 2014. This difference in size is related to the absence of pupils on the day of the interviewer's visit.

The mean age of C.T was 14.9 years with extremes of 10 years and 20 years.

Senegalese nationality was dominant $(73.9 \%)$ followed by Burkina Faso (3.9\%), and Gabon (3.6\%).

Urban C.T constituted $85.3 \%$ of the total population size (Table 1).

\subsection{Dental Caries and Associated Determinants}

The prevalence of dental caries in C.T. was $61.2 \%$. In their majority, children of troop have consumed sweet foods between main meals of the day, i.e. $85.9 \%$. These foods were made up of $38.3 \%$ candy. The other sugars represented $34 \%$ (Table 2). Relating to the habits of oral hygiene, only 2 pupils haven't cleaned their teeth versus 439 , i.e. $99.5 \%$. The method of brushing was horizontal at $57.9 \%$ and fluoridated pharmaceutical paste was used by $14.8 \%$ (Table 2).

In the younger category (age group $10-14$ years), the prevalence of caries was $55.5 \%$.

Brushing teeth several times a day was a protective factor and single dental brushing was 8.33 times more likely to have decay than those who brushed teeth several times a day but within the confidence interval IC $=[4.34-16,66]($ Table 2).

\section{Discussion}

\subsection{Limits and Methodological Considerations}

The survey has investigated the presence of dental caries noted only during the study period and not to its history which could be materialized either by a definitive filling or by an absent tooth. The factors associated with the carious pathology were then studied. It should be recalled that the medical examination of aptitude in force army requires candidates who have passed the MSS exam to 
Table 1. Distribution of sociodemographic characteristics of children of troop.

\begin{tabular}{|c|c|c|c|}
\hline Caracteristics & $\begin{array}{c}\text { Absolute } \\
\text { frequency }(n=441)\end{array}$ & $\begin{array}{c}\text { Relative } \\
\text { frequency }(\%)\end{array}$ & $\begin{array}{l}\text { Confidence } \\
\text { interval 95\% }\end{array}$ \\
\hline \multicolumn{4}{|l|}{ Age range } \\
\hline $10-13$ & 119 & 27.00 & $22.90-31.40$ \\
\hline $14-16$ & 209 & 47.40 & $42.70-52.20$ \\
\hline $17-20$ & 113 & 25.60 & $21.70-30.00$ \\
\hline \multicolumn{4}{|l|}{ Country } \\
\hline Benin & 11 & 2.50 & $1.30-4.60$ \\
\hline Burkina Faso & 17 & 3.90 & $2.30-6.20$ \\
\hline Cameroon & 1 & 0.20 & $0.00-1.50$ \\
\hline Centrafrique & 11 & 2.50 & $1.30-4.60$ \\
\hline Côte d'Ivoire & 14 & 3.20 & $1.80-5.40$ \\
\hline Gabon & 16 & 3.60 & $2.20-5.90$ \\
\hline Guinea Conakry & 8 & 1.80 & $0.80-3.70$ \\
\hline Mali & 12 & 2.70 & $1.50-4.80$ \\
\hline Mauritania & 5 & 1.10 & $0.40-2.80$ \\
\hline Niger & 12 & 2.70 & $1.50-4.80$ \\
\hline Senegal & 326 & 73.90 & $69.50-77.90$ \\
\hline Tchad & 8 & 1.80 & $0.80-3.70$ \\
\hline \multicolumn{4}{|l|}{ Origin } \\
\hline rural & 65 & 14.70 & $11.60-18.50$ \\
\hline urban & 376 & 85.30 & $81.50-88.40$ \\
\hline \multicolumn{4}{|c|}{$\begin{array}{c}\text { Educational } \\
\text { attaintment of father }\end{array}$} \\
\hline uneducated & 27 & 6.10 & $4.10-8.90$ \\
\hline Primary & 64 & 14.50 & $11.40-18.20$ \\
\hline Secondary & 95 & 21.50 & $17.90-25.70$ \\
\hline University & 255 & 57.80 & $53.10-62.50$ \\
\hline \multicolumn{4}{|c|}{$\begin{array}{l}\text { Educational } \\
\text { attaintment of mather }\end{array}$} \\
\hline uneducated & 49 & 11.10 & $8.40-14.50$ \\
\hline Primary & 170 & 38.50 & $34.00-43.30$ \\
\hline Secondary & 116 & 26.30 & $22.30-30.70$ \\
\hline University & 106 & 24.00 & $20.20-28.40$ \\
\hline
\end{tabular}

Table 2. Relationship between dental caries and other variables.

\begin{tabular}{|c|c|c|c|c|}
\hline \multirow{2}{*}{ Variables } & \multirow{2}{*}{ Response } & \multicolumn{2}{|c|}{ Dental caries } & \multirow{2}{*}{$\begin{array}{c}\text { Odds ratio (OR) } \\
\text { [confidence interval }]_{95 \%}\end{array}$} \\
\hline & & Yes & No & \\
\hline \multirow{2}{*}{ Origin } & Rural & $\begin{array}{c}40 \\
(61.50 \%)\end{array}$ & $\begin{array}{c}25 \\
(38.50 \%)\end{array}$ & \multirow{2}{*}{$\begin{array}{c}1.3 \\
\mathrm{IC}=[0.9-1.6]\end{array}$} \\
\hline & Urban & $230(61.20 \%)$ & $\begin{array}{c}146 \\
(38.80 \%)\end{array}$ & \\
\hline \multirow{2}{*}{ Nibbling } & Yes & $\begin{array}{c}255 \\
(67.30 \%)\end{array}$ & $\begin{array}{c}124 \\
(32.70 \%)\end{array}$ & \multirow{2}{*}{$\begin{array}{c}6.4 \\
\mathrm{IC}=[3.4-11.9]\end{array}$} \\
\hline & No & $15(24.20 \%)$ & $47(75.80 \%)$ & \\
\hline
\end{tabular}




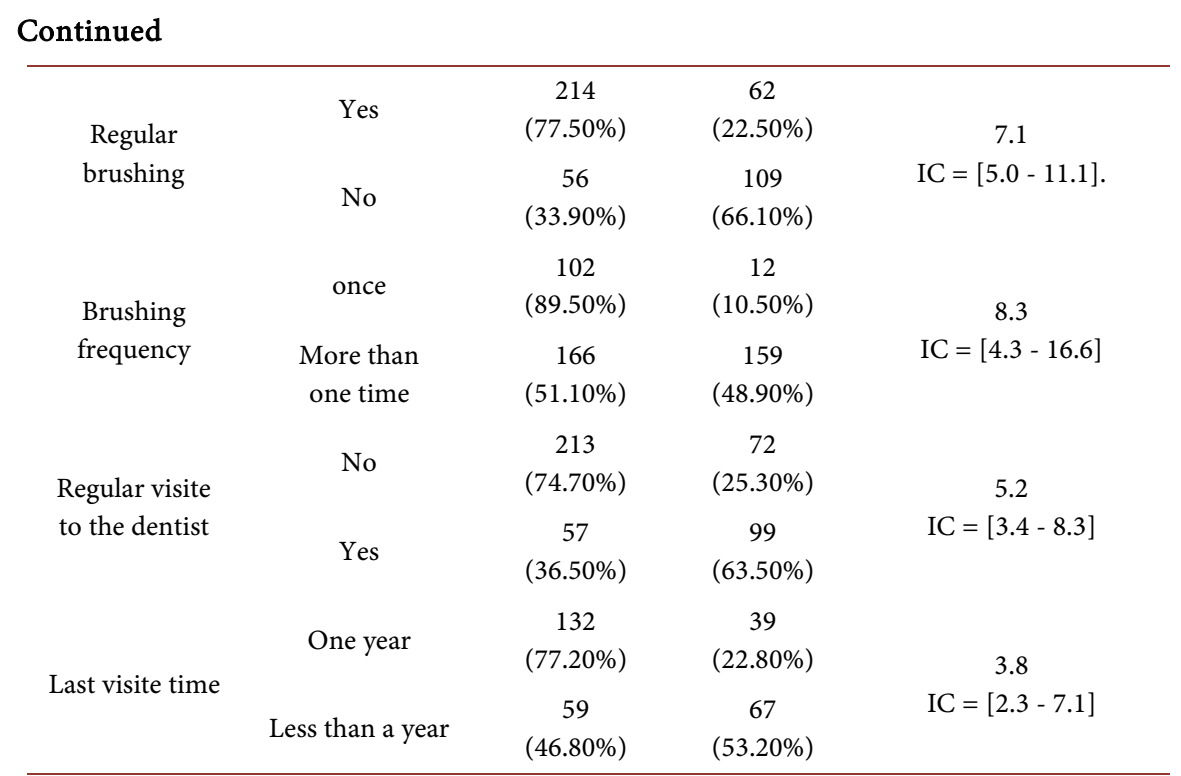

treat decayed teeth subject to their definitive admission. This may underestimate the severity of dental caries in children.

\subsection{General Considerations}

The situation of dental caries in this general educational institution with a military framework is rather worrying with an overall prevalence of $61.2 \%$. The latter is explained by factors whose statistical links with caries have been demonstrated in our study. These include sugar intake between meals, inadequate dental brushing, time to last visit of more than one year, and low awareness of regular brushing and regular visits.

Prevalence of tooth decay found by age groups was respectively $55.5 \%$ between 10 and 13 years, $63.6 \%$ between 14 and 16 years and $62.8 \%$ between 17 and 20 years. However, the mean age in the caries group was not statistically different from the mean age in the caries-free group $(p=0.594)$. Regardless of age, prevalence in the different age groups was high.

These prevalence proportions collected in the study are corroborated by global data of 2007 [5], and also by epidemiological surveys carried out in Senegal, which showed that $50 \%$ to $70 \%$ of the students examined were carrying at least one condition of dental disease [9] [10].

However, rates higher than those of our study are observed in a national pilot study on dental caries in Senegal [11]. The same is true in the Democratic Republic of Congo, Gabon, Morocco, Côte d'Ivoire, Cameroon [12] [13] [14] [15].

Rates lower than those of the MSS are also reported in Congo, in schools in Brazzaville [16], France, in 2005 on a sample of 1000 children of 12 years old, in 2002 in the Gironde [17].

Differences in prevalence (compared to MSS) are explained by the variation in determinants of tooth decay. Thus, the existence of dental offices with accessible services, the fluoride in water and the good behavior of the population in terms 
of oral hygiene, i.e. observing a good quality of dental brushing, contribute to a prevention of dental caries [18]. On the other hand, harmful consumption of sugar, inadequate dental brushing and a deficient oral health system contribute to a high prevalence, especially when there is no fluoride in the area and the population is in a situation of precariousness [19].

The lower prevalence of MSS can be explained by the accessibility of dental care to pupils (C.T) with the existence of a dental office located a few meters from the school and especially by the management of the decayed teeth before Admission to school. Dental brushing, although deficient, is widely practiced in MSS, where C.T also enjoy good living conditions. Behavioral determinants such as poor oral hygiene due to a dental brushing deficit also explain high prevalence observed elsewhere [13].

Areas with lower prevalence benefit from a better health care system as in France [17].

The existence of statistical links between the occurrence of dental caries and the risk factors are indicative of the high prevalence observed at the MSS.

In dental caries, the difference was statistically significant between sugar consumers between meals and others. There were $67.3 \%$, respectively, compared with $24.2 \%(p<0.001)$. Children troop consumers of sugars between meals were 6.44 times more likely to present dental caries than non-consumers. Indeed, the "westernization" of the food habits of the populations residing in the major African cities has led to an abusive consumption of sweets, confectionery and pastries, among others [15].

The degradation of the sugars fermentable to organic acids by the cariogenic bacteria of the plate (Streptococcus, Lactobacillus, Actinomyces) is responsible for demineralization of the enamel when the $\mathrm{pH}$ passes below 5.5 then the dentine, more fragile, Below 6.5.

The development of tooth decay arises from a lasting imbalance in favor of demineralization, i.e. when acid production is prolonged (prolonged and/or repeated contact time between bacteria, sugars and enamel tooth) and/or when the buffering capacity of the saliva is decreased [3].

In another study, a high prevalence of $81.4 \%$ was explained in part by the fact that $76.2 \%$ of students consumed more than three cariogenic foods per day [20].

\section{Conclusions}

This descriptive, cross-analytical study revealed a $62.1 \%$ prevalence of tooth decay and a statistically significant association of factors associated with its occurrence. The study showed links with the consumption of sugars between meals, dental brushing, last visit and awareness in relation to regular brushing and regular visits.

In view of this high prevalence, which could be harmful to health of the students of this school, it is necessary to implement a checkup plan focusing on factors identified and associated with tooth decay in the "Military school of Saint Louis". 


\section{References}

[1] Muller, M., Lupi-Pégurier, L., Medioni, E. and Bolla, M. (1997) Epidémiologie de la carie dentaire. [Epidemiology of Dental Caries.] Encycl. Méd. Chir. (Elsevier, Paris), Odontology, 23-0 1 0-A-20: 8 p.

[2] Lupi-Pégurier, L. and Bourgeois, M. (2010) Epidémiologie de la carie. [Epidemiology of Decay.] EMC Oral Medicine, 13.

[3] High Health Authority (2010) Stratégies de prévention de la carie dentaire. [Strategies for the Prevention of Tooth Decay.] Public Health Recommendations, Pitch.

[4] Kanoute, A., Cisse, D., Lô, C.M., Faye, D., Diouf, M. and Niang, A.M. (2015) Prévalence de la carie dentaire et des facteurs associés chez des enfants d'âge préscolaire dans trois régions du Sénégal. [Prevalence of Tooth Decay and Associated Factors in Pre-Schoolchildren in Three Regions of Senegal.] Dakar Med., 60, 54-63.

[5] Chaves, M., Coutress, T.W., Enwonwu, C.O., et al. (2007) Plan d'action pour la promotion de la santé bucco-dentaire et pour la prévention intégrée des affections Soixantième assemblé mondiale de la santé A60/16. [Action Plan for the Promotion of Oral Health and for the Integrated Prevention of Diseases Sixtieth World Health Assembly A60/16.] Report of the Secretariat 22 March 2007.

[6] Dargent-Pare, C. and Levy, G. (2001) Odontologie. In: Basdevant, A., Laville, M. and Lerebours, E., Eds, Traité de nutrition clinique de l'adulte. [Adult Clinical Nutrition Treaty.] Medicine-Sciences, Flammarion, 723, 609-612.

[7] Elani, H.W., Harper, S., Allison, P.J, Bedos, C. and Kaufman, J.S. (2012) Socio-economic Inequalities and Oral Health in Canada and the United States. Journal of Dental Research, 91, 865-870. https://doi.org/10.1177/0022034512455062

[8] OMS (2012) Santé bucco-dentaire. Centre des médias. [Oral health. Media Center.] Checklist N³18 AVRIL.

[9] Leye-Benoist, F., Bane, K., Aidara, A., Ndiaye, D., Chouker, Y. and Kane, A.W. (2014) Prévalence de la carie dentaire chez les élèves de 12 ans de la région de Dakar. [Prevalence of Tooth Decay among 12-Year-Olds in the Dakar Region.] Odonto Stomato Trop., 146, 58-64.

[10] Ministry of Education (2006) Introduction à l'école des compétences en santé pour lutter contre les maladies bucco-dentaires. Guide méthodologique du maître. Programme décennal de l'éducation et de la formation (PDEF). [Introduction to the school of healthskills to fight oral diseases. Methodological Guide of the master. Ten-year Programme of Education and Training (PDEF).]

[11] Aidara, A.W. and Bourgeois, D. (2014) Prévalence de la carie dentaire: Etude pilote nationale comparant l'indice de sévérité de la carie (CAO) vs ICDAS au Sénéga L. [Prevalence of Tooth Decay: A National Pilot Study Comparing the Severity Index of Decay (CAO) vs. ICDAS in Senegal.] Odonto-Stomatologie Tropicale, 145, 53-63.

[12] Tayanin, G.L., Ramanathan, J. and Bratthall, D. (2002) Caries Prevalence and Some Caries Related Factors for 12 Year-Old Children from Vientiane and Luang Prabang Provinces in Lao People's Democratic Republic. Odonto-Stomatologie Tropicale, 98, 19-26.

[13] Kaoutar, K., Hilali, M.K. and Loukid, M. (2013) La situation de la carie dentaire chez les adolescents de la Wilaya de Marrakech (Maroc). [The Situation of Tooth Decay in Adolescents of the Wilaya of Marrakech (Morocco).] Antropo, 29, 101-108.

[14] Majoli, S., Stoll, B., Manga, E., Rougemont, A. and Samson, J. (2006) Dental Hy- 
giene Habits in Cameroun Schoolchildren. Médecine Buccale Chirurgie Buccale, 12, 221-226. https://doi.org/10.1051/mbcb/2006002

[15] Koko, J., Ategbo, S., Ateba Ngoa, U. and Moussavou, A. (2009) Etude epidemiologique de la carie dentaire en milieu scolaire à Libreville, Gabon. [Epidemiological Study of Dental Caries in Schools in Libreville, Gabon.] Afican Journals Online, 6.

[16] Okoko, A.R., Ekouyabowassa, G. and Moyen, E. (2013) La carie dentaire en milieu scolaire à Brazzaville (Congo). [Dental Caries in Schools in Brazzaville (Congo).] Odonto-Stomatol Trop, 142, 25-30.

[17] UFSBD (2002) La santé dentaire en Gironde 2002. Enquête épidémiologique bucco-dentaire sur les enfants de 12 ans. [Dental Health in the Gironde 2002. Oral Epidemiological Survey of Children Aged 12.] 14 p.

[18] Olczak-Kowalczyk, D., Turska, A., Gozdowski, D. and Kaczmarek, U. (2016) Dental Caries Level and Sugar Consumption in 12-Year-Old Children from Poland. Advances in Clinical and Experimental Medicine, 25, 545-550. https://doi.org/10.17219/acem/61615

[19] Sheiham, A. and James, W.P. (2014) A New Understanding of the Relationship between Sugars, Dental Caries and Fluoride Use: Implications for Limits on Sugars Consumption. Public Health Nutrition, 17, 2176-2184. https://doi.org/10.1017/S136898001400113X

[20] Paglia, L., Scaglioni, S., Torchia, V., De Cosmi, V., Moretti, M., Marzo, G. and Giuca, M.R. (2016) Familial and Dietary Risk Factors in Early Childhood Caries. European Journal of Paediatric Dentistry, 17, 93-99. 